\title{
Terapi bedah pada vitiligo
}

\author{
Yessy Farina Salim ${ }^{1}$, Sri Lestari ${ }^{2}$ \\ 1. PPDS Fakultas Kedokteran, Universitas Andalas; 2. RSUP dr. M. Djamil, Padang
}

Korespondensi: Yessy Farina Salim, email: yessyfarina@gmail.com

\begin{abstract}
Abstrak
Vitiligo merupakan suatu gangguan pigmentasi kulit didapat, ditandai dengan adanya makula hipopigmentasi berwarna putih susu berbatas tegas disebabkan oleh hilangnya fungsi melanosit secara kronik dan progresif dari epidermis. Vitiligo merupakan penyakit multifaktorial, gangguan poligenik, dengan patogenesis yang masih belum jelas. Tujuan pengobatan adalah terhentinya progresivitas penyakit dan peningkatan repigmentasi. Terdapat tiga pola mekanisme repigmentasi pada vitiligo antara lain berawal dari unit folikel rambut (perifolikular), meluas dari tepi (marginal), dan difusa. Terdapat beberapa modalitas terapi diantaranya topikal, oral, foto terapi, tindakan bedah maupun alternatif. Tujuan: Untuk mengetahui terapi bedah pada vitiligo. Metode: Review yang dilakukan pada beberapa literatur atau jurnal yang membahas tentang vitiligo dan terapi bedah pada vitiligo. Hasil: Tindakan bedah dapat dibagi menjadi dua teknik dasar yaitu cangkok jaringan yang meliputi split thickness skin grafting, mini punch grafting, cangkok folikel rambut normal dan cangkok selular dengan atau tanpa pembiakkan melanosit. Simpulan: Prinsip dasar tindakan bedah pada vitiligo adalah usaha pembedahan untuk memperoleh repigmentasi lesi vitiligo yang dapat diterima secara kosmetik dengan transplantasi melanosit autolog dari kulit normal ke lesi vitiligo.
\end{abstract}

Kata kunci: pigmentasi kulit; vitiligo; terapi bedah

\begin{abstract}
Vitiligo is a skin pigmentation disorder characterized by the presence of a milky white hypopigmentation macule caused by the loss of chronic and progressive melanocyte function of the epidermis. Vitiligo is a multifactorial disease, a polygenic disorder, with pathogenesis that remains unclear. The goal of treatment is the cessation of disease progression and increased repigmentation. There are three patterns of repigmentation mechanisms in vitiligo, among others, from hair follicle units (perifollicular), extending from the edge (marginal), and diffuse. There are several therapeutic modalities such as topical, oral, phototherapy, surgical or alternative action. Objectives: To know surgical therapy in vitiligo. Methods: Review carried out in several literature or journals that discuss vitiligo and surgical therapy in vitiligo. Results: Surgical can be divided into two basic techniques, tissue graft which includes split thickness grafting skin, mini punch grafting, normal hair follicle graft and cellular graft with or without breeding melanocytes. Conclusions: The basic principle of surgical on vitiligo is a surgical attempt to obtain the reproduction of a cosmetically acceptable lesion of vitiligo by transplantation of autologous melanocytes from normal skin to vitiligo lesions.
\end{abstract}

Keywords: skin pigmentation; vitiligo; surgical therapy 


\section{PENDAHULUAN}

Vitiligo merupakan suatu gangguan pigmentasi kulit didapat, ditandai dengan adanya makula hipopigmentasi berwarna putih susu berbatas tegas disebabkan oleh hilangnya fungsi melanosit secara kronik dan progresif dari epidermis. ${ }^{1-3}$ Vitiligo merupakan penyakit multifaktorial, gangguan poligenik, dengan patogenesis yang masih belum jelas. Berbagai teori patogenesis vitiligo telah diungkapkan, namun yang paling diterima adalah faktor genetik dan non-genetik yang berinteraksi untuk mempengaruhi fungsi dan kelangsungan hidup melanosit, sehingga menyebabkan kerusakan autoimun dari melanosit. ${ }^{3}$

Terdapat beberapa bentuk klinis vitiligo antara lain fokal, segmental, generalisata dan universal. ${ }^{3}$ Prevalensi vitiligo diperkirakan 0,5-1\% dari populasi dunia, perempuan dan laki-laki mempunyai frekuensi yang sama banyak, menyebar di seluruh ras, namun bangsa kulit berwarna lebih banyak mengalami dampak psikososial dibandingkan dengan bangsa berkulit putih. ${ }^{4}$

Terdapat beberapa modalitas terapi di antaranya topikal, oral, foto terapi, tindakan bedah maupun alternatif. ${ }^{4}$ Tujuan pengobatan adalah terhentinya progresivitas penyakit dan peningkatan repigmentasi. Terdapat tiga pola mekanisme repigmentasi pada vitiligo antara lain berawal dari unit folikel rambut (perifolikular), meluas dari tepi (marginal), dan difusa. ${ }^{5}$
Untuk memperoleh repigmentasi lengkap, selain sering gagal, terapi tersebut di atas membutuhkan waktu yang lama dan sering menyebabkan pasien menjadi jemu, terutama jika lesi vitiligo muncul di daerahdaerah yang miskin cadangan melanosit seperti lesi-lesi di atas tonjolan tulang atau lesi vitiligo yang lama, sehingga intervensi ahli bedah sangat dibutuhkan untuk menyediakan melanosit normal pada daerah-daerah tersebut.

Artikel ini ditulis untuk mengetahui terapi bedah pada kasus vitiligo.

\section{METODE}

Artikel ini ditulis berdasarkan review yang dilakukan pada beberapa literatur atau jurnal yang membahas tentang vitiligo dan terapi bedah pada vitiligo.

\section{HASIL DAN PEMBAHASAN}

Terapi yang ideal adalah terapi yang berdasarkan etiologi dan patogenesis penyakit. Namun karena etiologi belum sepenuhnya jelas maka pengobatan didasarkan pada teori patogenesis yang ada, sebagian besar terapi bersifat simptomatik. Tujuan dari penatalaksanaan vitiligo adalah repigmentasi dan stabilisasi dari proses depigmentasi. ${ }^{6}$

Terapi umum yang paling penting pada penderita vitiligo adalah menghindari faktor pencetusnya seperti bahan kimia, trauma mekanis, trauma saraf, stres psikis, paparan sinar ultraviolet dan radikal bebas. ${ }^{7}$ Sedangkan pada terapi sistemik, 
deksametason oral sebagai terapi denyut selama 24 minggu memberikan hasil yang bervariasi pada vitiligo generalisata. Terapi ini dapat mencegah perkembangan depigmentasi pada vitiligo yang aktif. Deksametason diberikan $10 \mathrm{mg}$ dosis tunggal setiap minggu selama 2 hari berturut-turut, kemudian 5 hari tanpa pengobatan. Deksametason di sini bekerja sebagai imunosupresif. Sehubungan dengan risiko efek samping, obat ini tidak direkomendasikan. ${ }^{8}$

Pada vitiligo dengan onset dini dan terlokalisir, steroid topikal potensi kuat dan sangat kuat direkomendasikan sekurang-kurangnya selama 2 bulan. Atrofi kulit merupakan efek samping yang paling sering ditemukan. Pimekrolimus dan takrolimus topikal sebagai imunomodulator dapat digunakan sebagai alternatif terapi karena efek samping dan keamanannya lebih baik daripada steroid potensi kuat. Depigmentasi dengan $p$ (benzyloxy) phenol (monobenzyl ether hidroquinon) dapat digunakan pada vitiligo luas pada dewasa (depigmentasi $>50 \%$ atau depigmentasi luas pada wajah dan tangan) yang tidak dapat dilakukan repigmentasi dan tidak terjadi tanning permanen. ${ }^{8}$

Foto terapi narrow band ultraviolet $B$ (NBUVB) atau psoralen-ultraviolet $A$ (PUVA) dapat digunakan untuk terapi vitiligo yang tidak dapat diobati secara konservatif, vitiligo yang luas atau vitiligo terlokalisir dengan gangguan kualitas hidup yang signifikan. Pengobatan ini dapat dilakukan pada penderita vitiligo dengan tipe kulit yang lebih gelap dan dimonitor dengan fotografi serial setiap 2-3 bulan. $^{8}$

Terapi bedah pada vitiligo diindikasikan pada pasien dengan vitiligo stabil yang tidak respon terhadap terapi medis atau yang menyebabkan stres psikologis yang berat. Terapi ini dapat juga dilakukan pada pasien dengan leukoderma karena luka bakar, piebaldism, inactive discoid lupus erythematosus dan penyakit lain yang menyebabkan depigmentasi permanen. Kontraindikasi terapi bedah pada vitiligo adalah pasien dengan vitiligo tidak stabil dan vitiligo pada anak. Pada anak, perjalanan penyakitnya sulit diprediksi dan memberikan respon terapi medis yang lebih baik dibanding pasien dewasa. ${ }^{5}$

Prinsip dasar tindakan bedah pada vitiligo adalah usaha pembedahan untuk memperoleh repigmentasi lesi vitiligo yang dapat diterima secara kosmetik, melalui cangkok melanosit autolog dari kulit normal ke lesi vitiligo. Terdapat beberapa modalitas tindakan bedah pada vitiligo, hasil yang baik bila terdapat repigmentasi komplit dan secara kosmetik diperoleh warna kulit sama dengan kulit normal sekitarnya. Tindakan ini tidak dapat menghentikan progresivitas penyakit, dan diindikasikan untuk lesi vitiligo yang stabil yang tidak memperlihatkan respon terhadap pengobatan medis. Tindakan bedah dapat dibagi menjadi dua teknik dasar yaitu cangkok jaringan dan cangkok selular. ${ }^{5,8}$ 
Cangkok jaringan yaitu epidermis normal yang kaya melanosit, baik secara terpisah maupun dengan jaringan dermis dicangkokkan pada daerah yang mengalami depigmentasi. Cangkok selular yaitu sel-sel epidermis normal yang mengandung melanosit maupun hanya melanosit yang telah dipisahkan dari komponen epidermal lainnya, dipisahkan dari jaringan donor, selanjutnya baik tanpa pembiakan di laboratorium maupun dibiakkan terlebih dahulu, dicangkokkan pada daerah yang mengalami depigmentasi. ${ }^{9}$

Cangkok jaringan terdiri atas beberapa teknik yaitu split thickness skin grafting, mini punch grafting, dan cangkok folikel rambut normal. (1) Split thickness skin grafting: Keuntungan dari split thickness skin grafting adalah bahwa pigmentasi langsung dapat mencakup daerah yang lebih luas dalam periode waktu yang singkat dibandingkan dengan teknik lain. Daerah yang sulit seperti kelopak mata, kantus medial mata, areola, puting, dan daerah genital dapat diterapi dengan mudah. Pigmentasi yang dihasilkan seragam dan cobblestoning yang umum ditemukan pada punch grafting tidak terlihat. ${ }^{6,10}$ Kekurangannya adalah Hiperpigmentasi yang lama biasa terlihat. Teknik ini membutuhkan keterampilan operator untuk mendapatkan cangkok kulit yang translusens. Jika operator kurang terlatih, donor yang diambil tidak cukup tipis, kulit donor banyak yang terbuang dan akan menyisakan parut pada penyembuhan luka donor. ${ }^{6}(2)$ Mini punch grafting: Teknik ini paling mudah dan murah serta dapat dilakukan pada semua daerah selain puting dan sudut bibir dimana kontraksi otot dapat mengganggu penyerapan graft. Teknik ini juga dapat dilakukan pada daerah yang sulit untuk diobati seperti jari-jari kaki, telapak tangan dan kaki. ${ }^{8}$ Kekurangannya, teknik ini tidak dapat digunakan pada lesi vitiligo yang luas dimana pigmentasi yang seragam tidak selalu dapat dicapai. Kekurangan penting lainnya adalah lepasnya cangkokan serta munculnya cobblestoning dan polka dot appearance. $^{8}$ (3) Cangkok folikel rambut normal: Kelebihan menggunakan folikel rambut tunggal dalam cangkok melanosit untuk lesi vitiligo adalah folikel rambut mengandung melanosit lebih banyak dari kulit yang tidak berambut, melanosit folikel rambut lebih resisten terhadap berbagai bahan perusak melanosit yang pernah ditemukan pada lesi vitiligo, cobblestone belum pernah dilaporkan, mudah dikerjakan pada lesi vitiligo yang kecil, dan dapat dilakukan pada daerah yang sulit. ${ }^{11}$ Namun kekurangannya teknik ini hanya efektif pada lesi vitiligo berukuran kecil. Ini adalah prosedur rumit yang memerlukan keahlian dan waktu. Jaringan parut terjadi di daerah oksipital dimana cangkok diambil. ${ }^{5,11}$

Cangkok seluler dapat dilakukan dengan cangkok melanosit tanpa pembiakan maupun dengan pembiakan. (1) Cangkok melanosit tanpa pembiakan ini lebih disukai karena tidak membutuhkan waktu yang lama, biaya lebih rendah dibandingkan cangkok melanosit dengan 
pembiakan. ${ }^{11,12}$ Namun kekurangannya, teknik ini membutuhkan tenaga terlatih dan peralatan yang sering tidak selalu tersedia serta sering dijumpai ketidakcocokan warna kulit di area resipien dengan kulit sekitarnya. ${ }^{12}$ (2) Cangkok melanosit dengan pembiakan memiliki kelebihan lesi vitiligo yang luas dapat diatasi dengan donor yang berukuran sangat kecil. ${ }^{13}$ Kekurangannya teknik ini memerlukan biaya yang besar, waktu yang lama, alat-alat laboratorium yang lebih canggih dan tenaga terampil di bidang biakan sel. Dibandingkan dengan cangkok melanosit tanpa biakkan, repigmentasi cangkok melanosit dengan biakkan ternyata berjalan lebih lambat. ${ }^{13}$

\section{SIMPULAN}

Prinsip dasar tindakan bedah pada vitiligo adalah usaha pembedahan untuk memperoleh repigmentasi lesi vitiligo yang dapat diterima secara kosmetik dengan transplantasi melanosit autolog dari kulit normal ke lesi vitiligo. Tindakan bedah dapat dibagi menjadi dua teknik dasar yaitu cangkok jaringan dan cangkok selular. Tindakan ini tidak dapat menghentikan progresivitas penyakit, dan diindikasikan untuk lesi vitiligo yang stabil yang tidak memperlihatkan respon terhadap pengobatan medis.

\section{DAFTAR PUSTAKA}

1. Ortonne JP. Vitiligo and other disorders of hypopigmentation. Dalam: Bolognia JL, Jorizzo JL, Rapini RP, Callen JP, Horn TD, Mancini AJ, et al (editor). Dermatology Volume 1. 2nd edition. New York: Mosby Elsevier; 2008. P.913-20.

2. Rezaei N, Gavalas NG, Weetman AP, Kemp EH. Autoimmunity as an aetiological factor in vitiligo. JEADV. 2007; 21:865-76.

3. Birlea SA, Spritz RA, Norris DA. Vitiligo. Dalam: Goldsmith LA, Katz SI, Gilchrest BA, Paller AS, Leffell DJ, Wolff K, eds. Fitzpatrick's dermatology in general medicine, Volume 1. 8th ed; vol. 1. New York: McGraw Hill; 2012. P.792-803.

4. Oiso N, Suzuki T, Wataya-Kaneda M, Tanemura A, Tanioka M, Fujimoto T, et al. Guidelines for diagnosis and treatment of vitiligo in Japan. J Dermatol. 2013; 40(5):34454.

5. Khunger N, Kathuria SD, Ramesh V. Tissue graft in vitiligo surgery - past, present, and future. Indian J Dermatol Venereol Leprol. 2009; 54(2):150-8.

6. Samim F, Sultan S, Ahmad Q. Split thickness skin grafting in patients with stable vitiligo. J Cutan Aesthet Surg 2011; 4(1):38-40.

7. Falabella R. Repigmentation of leukoderma by minigraft of normally pigmented, autologous skin. J Dermatol Surg Oncol. 1978; 4(12):916-19. 
8. Gawkrodger DJ, Ormerod AD, Shaw L. Guideline for the diagnosis and management of vitiligo. British Journal of Dermatology. 2008; 159:1051-1076.

9. Yaghoobi R, Omidian M, Bagherani N. Vitiligo: A review of the published work. Journal of Dermatology. 2011; 38:419-31.

10. Mehta N, Shah K, Theodore C, Vias V, Patel A. Epidemiologic study of vitiligo in Surat area, South Gujarat. Indian J Med Res. 1993; 61:145-54.

11. Mapar MA, Safarpour M, Haghighizadeh MH. A comprehensive study of the mini-punch grafting and hair follicle transplantation in the treatment of refractory and stable vitiligo. J Am Acad Dermatol. 2014; 70(4):743-7.

12. Gauthier Y, Surleve-Bazeille JE. Autologous grafting with non-cultured melanocytes: a simplified method for treatment of depigmented lession. J Am Acad Dermatol. 1992; 26:191-4.

13. Kumar R, Parsad D, Kanwar A, Kaul D. Development of melanocyte-keratinocyte cocultured model for controls and vitiligo to assess regulators of pigmentation and melanocytes. Indian J Dermatol Venereol Leprol. 2012; 78(5):599-604. 